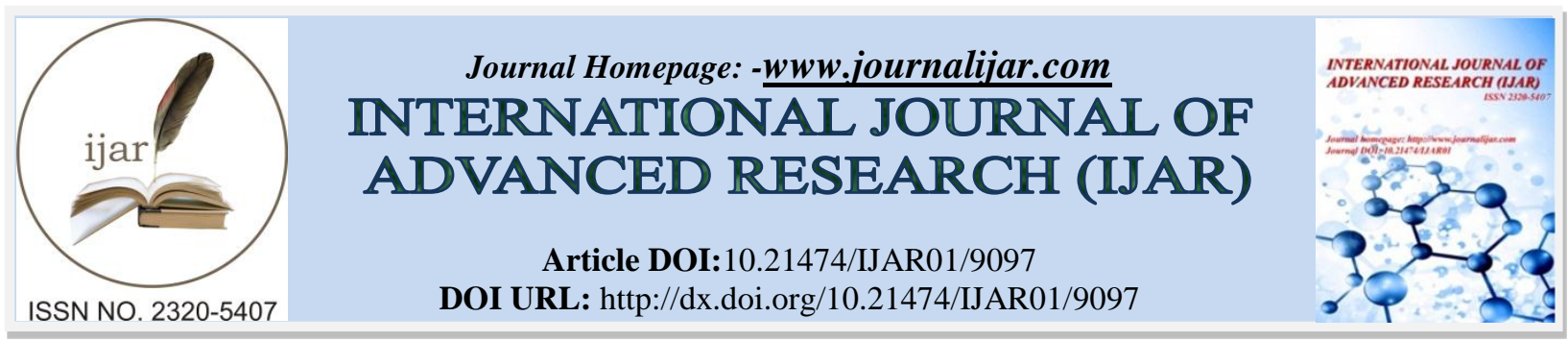

RESEARCH ARTICLE

\title{
AN EFFICIENT SOLVENT EXTRACTION METHOD FOR NIOBIUM AND TANTALUM BY LAURYL ALCOHOL IN KEROSENE.
}

Laila. A. Guirguis, Nagwa, A. Falila, Hend. M. Salem and M. El Ahmady Ibrahim. Nuclear Materials Authority, P.O. Box 530 El Maadi, Cairo, Egypt.

\section{Manuscript Info}

\section{Manuscript History}

Received: 20 March 2019

Final Accepted: 22 April 2019

Published: May 2019

Key words:-

Niobium, Tantalum, Solvent extraction,

Lauryl alcohol.

\begin{abstract}
The render study on physically upgrade ore sample from Abu Rusheid contents 22.2 in wt. $\% \mathrm{Nb}$ and 2.5 in wt. \% Ta. The sample is fused with a mixture of sodium dihydrogene phosphate monohydrate and of disodium hydrogen phosphate in platinum cresbol and the metal was dissolved in water. Extraction of $\mathrm{Ta}(\mathrm{V})$ and $\mathrm{Nb}(\mathrm{V})$ from the solution was carried out by $0.1 \mathrm{M}$ lauryl alcohol in kerosene. The factors of $\mathrm{pH}$, contact time, temperature, settling time and $\mathrm{A} / \mathrm{O}$ phase ratio were studied. Stripping of $\mathrm{Nb}(\mathrm{V})$ and $\mathrm{Ta}(\mathrm{V})$ was performed using $5 \mathrm{M} \mathrm{H}_{2} \mathrm{SO}_{4}$ for $\mathrm{Nb}(\mathrm{V})$ and distilled water for $\mathrm{Ta}(\mathrm{V})$ at $\mathrm{O} / \mathrm{A}$ phase ratio $1: 1$ in two stages. The final recovery of $\mathrm{Nb}_{2} \mathrm{O}_{5}$ and $\mathrm{Ta}_{2} \mathrm{O}_{5}$ was $89 \%$ and $94 \%$ respectively. Stripe solution of $\mathrm{Nb}$ and $\mathrm{Ta}$ was precipitate by ammonia at $\mathrm{pH}$ 6.5-7.5 and $\mathrm{pH}$ 4.5-5.5 respectively and the product was confirmed by EDAX, XRD and FTIR analysis. Finally a technical flow sheet was constructed.
\end{abstract}

Copy Right, IJAR, 2019,. All rights reserved.

\section{Introduction:-}

The niobium-tantalum ore in Abu Rusheid area was classified as refractory mineral of low-grade which was mainly composed of columbite. The $\mathrm{Nb}$ - $\mathrm{Ta}$ mineralization (columbite) at Abu Rusheid area has been known since the end of 1970s when a joint Soviet -Egyptian team, completed an evaluation based on the results of 1365 geochemical samples. Abu Rusheid was not explored until now but estimated as a big deposit accounting for ore reserves of 13 thousand tons of $\mathrm{Ta}_{2} \mathrm{O}_{5}$ and 90 thousand tons of $\mathrm{Nb}_{2} \mathrm{O}_{5}$ in contents amounting to 0.02 and of $0.14 \%$ respectively (Sabet et, al; 1976).Recently, Nuclear Materials Authority (NMA) launched a comprehensive exploration program in Wadi Al Gamal Basin since (2002) for Nuclear resources (REEs, $\mathrm{Zr}, \mathrm{Nb}-\mathrm{Ta}, \mathrm{Th}, \mathrm{U}, \mathrm{Ag}, \ldots$ ) in the cataclastic rocks of Wadi Abu Rusheid area (Fig.1) (Ibrahim et al., 2002 and 2004).

According to United States Geological Survey (USGS), the global reserves of tantalum are larger than 100,000 tons, of which about $62 \%$ are found in Australia and about $36 \%$ in Brazil. The largest two tantalum deposits are both in Australia. Nowadays, about $15 \%$ to $20 \%$ of the total tantalum production is from waste recycling processes (Hintemann et al., 2018).

Corresponding Author:-Laila. A. Guirguis.

Address:-Nuclear Materials Authority, P.O. Box 530 El Maadi, Cairo, Egypt. 
The decomposition of tantalite- and niobium-bearing concentrates and obtainment of metal tantalite and niobium or their compounds is one of the most complex problems of rare metal technologies (Mehmet et al., 2018). The niobium- tantalum minerals associated with rare earth mainly exist in the form of multiple oxides, were readily leached under strong acidic conditions (Wang et al., 2012, Kumar et al., 2011).These minerals are often treated with many methods to extract the valuable metals, such as acid leaching, alkaline leaching, and roasting followed by hydrofluoric acid and electrolytic leaching (Zhang et al., 2011, Janacek et al., 2017). The separation and purification of these metals is mainly performed by extraction.

Two types of extraction flow sheets are used. The first type includes joint extraction of tantalum (V) and niobium (V) followed by their separation in the backwashing stage. The second type is based on successive selective recovery of tantalum (V) and niobium (V). To improve extractive separation of Ta (V) from $\mathrm{Nb}(\mathrm{V})$, an additional mineral acid (as a rule, sulfuric acid) is added into the solution. The $\mathrm{H}_{2} \mathrm{SO}_{4}$ concentration in this solution should be relatively low, and the lower, the stronger the extractant basicity (Nikolayev et al., 2002).

All niobium minerals can be decomposed by hydrofluoric acid with complete dissolution, and this method is widely used for the dissolution of niobium-tantalum minerals (Zhou, et al., $2005 \&$ 2011).However, concentrated hydrofluoric acid was easy to volatilize, which caused serious pollution problems (Zhou et al., 2004). Anatoly et al., (2004) applied liquid extraction of tantalum with 2 octanol. Where Maiorov, et al., (2010, 2013, 2015\&2016) studied extraction recovery of Ta (V) and $\mathrm{Nb}(\mathrm{V})$ with octanol from HF acid solution containing large amount of Ta (V). Nikolover, et al., (2009) developed the flow sheet for the preparation of pure tantalum and niobium oxide. Kasikava, et al., (2009 \&2010) developed a process for converting $\mathrm{Ta}(\mathrm{V}), \mathrm{Nb}(\mathrm{V}), \mathrm{Ti}(\mathrm{V})$ sulphates and chlorides to their fluorides in order to improve separation of these elements. They extract $\mathrm{Nb}(\mathrm{V})$ from hydrochloride solution with tertiary amines in a protect diluents.A more trials for acid breakdown, leaching and extraction from some Egyptian ore material are given by El Huesani, (1996), El Hazek, (2001), Amer, (2007), El Hazek, et al., $(2009,2010)$.

\section{Geologic Setting}

A geologic map of Abu Rusheid area was constructed $\left(3 \mathrm{~km}^{2}\right)$ on the base of a grid pattern $20 \mathrm{x} 20 \mathrm{~m}$ (Figure .1) about $2 \mathrm{~km}^{2}$ cataclastic rocks (host rock for $\mathrm{Nb}-\mathrm{Ta}$ ). The cataclastic rocks of Abu Rusheid area are highly sheared and characterized by banding (N-S) and cross-cut by perpendicular two shear zones generally (N-S and E- W). The cataclastic rocks are subdivided into: a) protomylonite, b) mylonite, c) ultramylonite and d) quartzite with gradational contacts. Columbite- tantalite occurs abundantly as disseminated minute grains either as single crystal or aggregates, visible by naked eyes (Ibrahim et al., 2002 \&2004).

Niobium content in Abu Rusheid area, ranges from 300 to $2000 \mathrm{ppm}$ and forms high concentrated occurrences in the southern part of the study area (Fig.1) and covers an area of about $1,500,000 \mathrm{~m}^{2}$ with average content $500 \mathrm{ppm}$. The estimated $\mathrm{Nb}$ was based on the evaluation over Wadi Abu Rusheid level (385m). The $\mathrm{Nb}$ - map (Fig.2) excludes all $\mathrm{Nb}$-grade more than $0.1 \%$. The $\mathrm{Nb} / \mathrm{Ta}$ ratio is around 10. Abu Rusheid inferred resources are calculated on the basis of more than $100 \mathrm{ppm} \mathrm{Ta}$ and $500 \mathrm{ppm}$ $\mathrm{Nb}$ as an average (Ibrahim et al., $2008 \& 2018$ ) as follows:

\begin{tabular}{|l|l|l|l|l|l|}
\hline Trace Elements & $\begin{array}{l}\text { Average } \\
\text { Thickness } \\
(\mathbf{m})\end{array}$ & $\begin{array}{l}\text { Surface } \\
\text { Area }\left(\mathbf{m}^{2}\right)\end{array}$ & $\begin{array}{l}\text { Tonnage } \\
\left(\mathbf{m}^{3}\right)\end{array}$ & $\begin{array}{l}\text { Ore Grade } \\
(\boldsymbol{\%})\end{array}$ & Ore Metal (Tons) \\
\hline Niobium $(\mathbf{N b})$ & $\mathbf{7 5}$ & $\mathbf{1 , 5 0 0 , 0 0 0}$ & $\mathbf{2 2 0 , 0 0 0 , 0 0 0}$ & $\mathbf{0 . 0 5}$ & $\mathbf{8 6 , 1 7 0}$ \\
\hline
\end{tabular}

The majority of mineral grains are considered Ferro-columbite with minor amounts of Ta and Mn. The corresponding chemical analyses are shown in Table (1). The results indicate the presence of excess of $\mathrm{UO}_{2}$ and $\mathrm{P}_{2} \mathrm{O}_{5}$ in some samples. Other columbite grains seem to be contaminated with various mica types. $\mathrm{Nb}_{2} \mathrm{O}_{5}$ contents range from 40.13 to74.45 in wt. \%, while $\mathrm{Ta}_{2} \mathrm{O}_{5}$ varies from 2.64 to 6.70 in wt. $\%$. Columbite is commonly in association with $\mathrm{Fe}-\mathrm{Ti}$ oxides and $\mathrm{U}-\mathrm{Pb}$ mineral (most probably kasolite). In view of the ore side, it is of scientific and practical interest to carry out a systematic investigation in 
order to find out the appropriate condition for separating each of $\mathrm{Ta}(\mathrm{V})$ and $\mathrm{Nb}(\mathrm{V})$ using an efficient breakdown and leaching reagent beside a new solvent.

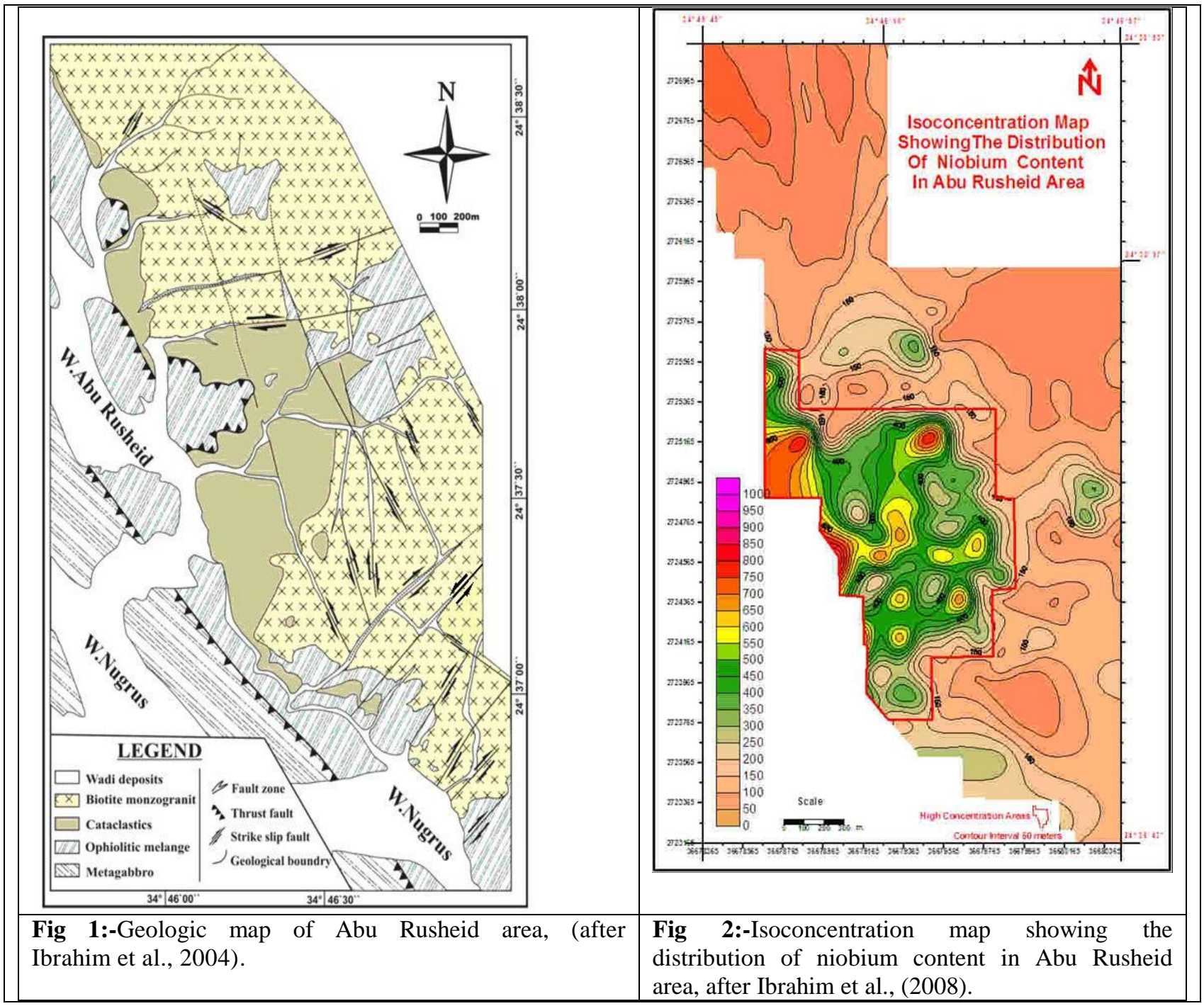

Table 1:-Results of ESEM analyses for ferrcolumbite, Abu Rusheid cataclastic rocks

\begin{tabular}{|c|c|c|c|c|c|c|c|}
\hline & 1 & 2 & 3 & 4 & 5 & 6 & 7 \\
\hline $\mathbf{P}_{2} \mathbf{O}_{5}$ & 3.72 & 0 & 0 & 0 & 0 & 0 & 0 \\
\hline $\mathrm{CaO}$ & 0.24 & 0.2 & 0.33 & 0.33 & 0.25 & 1.65 & 1.46 \\
\hline $\mathrm{TiO}_{2}$ & 0.63 & $\mathbf{0}$ & 0.67 & 0.63 & 0.38 & 0.42 & 0 \\
\hline MnO & 2.22 & 3.61 & 2.98 & 3.47 & 3.32 & 0.33 & O \\
\hline $\mathrm{Fe}_{2} \mathrm{O}_{3}$ & 15.13 & 13.8 & 13.61 & 22.78 & 14.77 & 3.58 & 3.46 \\
\hline $\mathrm{TaO}$ & 3.62 & 4.74 & 4.76 & 5.87 & 6.70 & 3.09 & 2.64 \\
\hline $\mathrm{Nb}_{2} \mathrm{O}_{5}$ & 74.45 & 72.58 & 66.19 & 60.47 & 69.61 & 50.16 & 40.13 \\
\hline 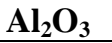 & 0 & 1.67 & 1.25 & 2.03 & 0 & 1.58 & 2.56 \\
\hline $\mathbf{Y}_{2} \mathbf{O}_{3}$ & 0 & 2.45 & 0 & 0 & 0 & $\mathbf{0}$ & 14.07 \\
\hline $\mathrm{UO}_{2}$ & 0 & 0.54 & 4.85 & 0 & 0.64 & 20.09 & 18.84 \\
\hline $\mathrm{K}_{2} \mathrm{O}$ & 0 & 0.4 & 0.74 & 0 & 0 & 1.89 & 1.38 \\
\hline $\mathrm{SiO}_{2}$ & 0 & $\mathbf{0}$ & 4.27 & 4.42 & 4.18 & 4.33 & 4.54 \\
\hline $\mathrm{ThO}_{2}$ & 0 & 0 & $\mathbf{0}$ & $\mathbf{0}$ & 0.16 & 2.26 & 0 \\
\hline $\mathbf{P b O}$ & 0 & $\mathbf{0}$ & $\mathbf{0}$ & $\mathbf{0}$ & 0 & 9.07 & 3.34 \\
\hline
\end{tabular}




\begin{tabular}{|l|l|l|l|l|l|l|l|}
\hline Total & $\mathbf{1 0 0}$ & $\mathbf{9 9 . 9 9}$ & $\mathbf{9 9 . 9 9}$ & $\mathbf{1 0 0}$ & $\mathbf{1 0 0}$ & $\mathbf{1 0 0}$ & $\mathbf{1 0 0}$ \\
\hline
\end{tabular}

\section{Extraction}

Ore Opening (Preparation of sample solution):

Four grams of sodium dihydrogene phosphate monohydrate and four grams of disodium hydrogen phosphate were mixed well in a dry platinum crucible, heated slowly first on wire gauze, and then strongly on the flame for the formation of condensed phosphate. An accurately weighed $0.5 \mathrm{~g}$. sample portion was added to the cooled melt. The crucible with the content was heated on the flame for fusion with swirling. After 3-4 minutes, the crucible was covered with a platinum lid and kept on the burner for complete decomposition (about 5 minutes). The crucible was swirled intermittently, cooled and transferred in to a $250-\mathrm{ml}$ beaker containing distilled water. The beaker was heated on a water bath for dissolution of the melt. The crucible was removed from the beaker, washed thoroughly, and the volume was made to $100 \mathrm{ml}$.

\section{Analytical procedures}

To define the mineralogical composition of the working ore material, the bulk and separated picked grains were subjected to: 1)-X-Ray diffraction analysis using a Philips X-ray diffract meter, model PW 223/2Ө. In this analysis, the copper tube was operated at $40 \mathrm{KV}$ and mA.3. 2) -Environmental scanning electron microscope (ESEM), Philips X1.30 and 4) - ICP Standards and calibration curve. The measurement was performed using simultaneous inductively coupled plasma emission spectrometer (720 ICP-OES, Agilent Technologies). Samples were introduced via glass concentric nebulizer fitted to glass cyclonic spray chamber (single pass).

\section{Solvent extraction of $\mathrm{Nb}$ and $\mathrm{Ta}$}

Extraction of $\mathrm{Nb}$ and $\mathrm{Ta}$ was carried out using the organic solvent Lauryl alcohol. The solvent was diluted in kerosene to prepare different concentrations. In an each extraction experiment, the organic phase was conducted with the aqueous phase as in separating funnel where they were shaken together for the desired time. The two phases were then allowed to settle, separate and an aliquot sample of the aqueous phase was analyzed for its remaining metal content in order to calculate the distribution coefficient.

\section{Extraction Isotherm and construction of Mac Cabe Thiele diagram for the extraction process}

$10 \mathrm{gm}$ of both organic $(0.1 \mathrm{M}$ Lauryl alcohol in kerosene and aqueous phase are contacted for 15 mines until equilibrium is attained. The phases are allowed to separate and aqueous phase is removed from the separating funnel and analysis. Fresh aqueous solution is then added to the funnel containing the remainder of the organic phase in an amount to give the same phase ratio as the originally used. The two phases are again contracted until equilibrium is obtained. This process is carried out until saturation of the solvent with $\mathrm{Nb}$ or $\mathrm{Ta}$ is obtained, $\mathrm{pH}$ should be adjusted to 0.25 for $\mathrm{Nb}$ and 2 for Ta. The obtained data were used to obtain the equilibrium curve. The next step in the construction of McCabe-Thiele diagram was to try a numbers of operating lines. The slope is equal to the ratio of organic/aqueous volumes. At each operating line, the theoretical number of stages could be stepped of upon the diagram.

\section{Equilibrium line and construction of Mc-Cabe Thiele diagram for the stripping:}

In this study $10 \mathrm{gm}$ loaded organic $\left(0.1 \mathrm{M}\right.$ lauryl alcohol, in kerosene and $10 \mathrm{gm}$ of $5 \mathrm{M} \mathrm{H}_{2} \mathrm{SO}_{4}$ (stripping reagent for $\mathrm{Nb}$ ) are contacted for 10 mines until equilibrium is attained. The phases are allowed to separate. A measured portions of the aqueous phase is taken for analysis. Fresh loaded $0.1 \mathrm{M}$ lauryl alcohol is added to the separating funnel containing the remainder of the aqueous phase in amount to give the same phase ratio as original ore used. The same procedure is carried out. This process is carried out until solution of the aqueous phase with $\mathrm{Nb}$ is obtained. The same procedure is done for $\mathrm{Ta}$ except that the stripping agent is distilled water.

\section{Precipitation}

Precipitation of each of $\mathrm{Nb}(\mathrm{V})$ and $\mathrm{Ta}(\mathrm{V})$ solution, each of the solution of $\mathrm{Nb}$ and $\mathrm{Ta}$ was precipitated by ammonia solution at $\mathrm{pH}$ 6-7.5 for $\mathrm{Nb}$ and 4.5-5.5 for $\mathrm{Ta}$ and calcined at $650{ }^{\circ} \mathrm{C}$ for 3 hrs. Finally a proposed technical flow sheet is given in Fig. (23). 


\section{Results \& Disccusion:-}

Analysis of bulk sample:

Table 2:-shows average concentration of major oxides (wt. \%) and trace elements (ppm) in mylonite sample, Abu Rusheid area

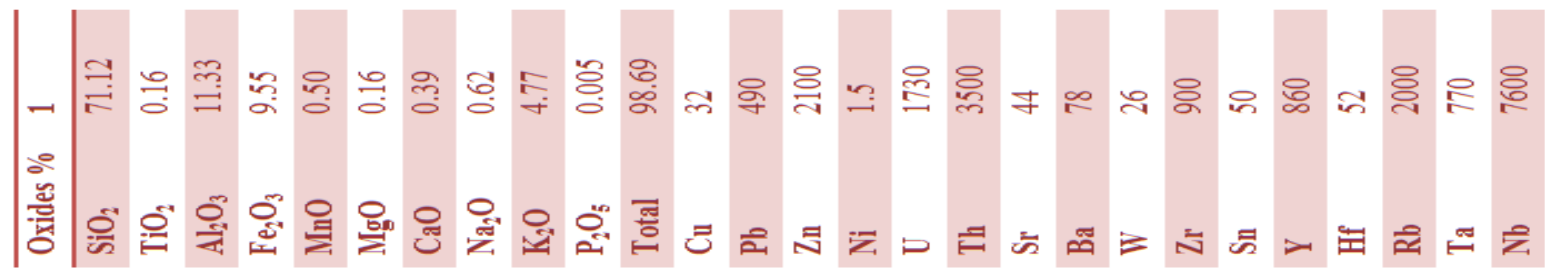

Chemical analysis:

Complete chemical analysis of the physically upgraded ore sample form Abu Rusheid mylonite is shown in Table (3) as defined by ICP.

Table 3:-Chemical analysis of the studied sample

\begin{tabular}{|l|l|l|l|}
\hline Major constituent & Wt. $(\%)$ & Trace constituent & Wt. $(\%)$ \\
\hline $\mathrm{SiO}_{2}$ & 29.5 & Nb & 22.2 \\
$\mathrm{TiO}_{2}$ & 1.2 & $\mathrm{Ta}$ & 2.5 \\
$\mathrm{Al}_{2} \mathrm{O}_{3}$ & 12.3 & & \\
$\mathrm{Fe}_{2} \mathrm{O}_{3}$ & 21.3 & & \\
$\mathrm{CaO}$ & 1.1 & & \\
$\mathrm{MgO}$ & 0.5 & & \\
$\mathrm{MnO}$ & 2 & & \\
$\mathrm{Na}$ & 1.02 & & \\
$\mathrm{~K}_{2} \mathrm{O}$ & 2.8 & & \\
$\mathrm{P}_{2} \mathrm{O}_{5}$ & 0.3 & & \\
L.O.I & 0.4 & & \\
Total & & & \\
\hline
\end{tabular}

\section{Characteristics}

X-Ray diffraction pattern

Figure (3) shows XRD pattern of $\mathrm{Nb}$ ore sample from Abu Rusheid mylonite, while Ta not clear on the figure because of its less contents (less than $5 \mathrm{wt} . \%$ in the sample).

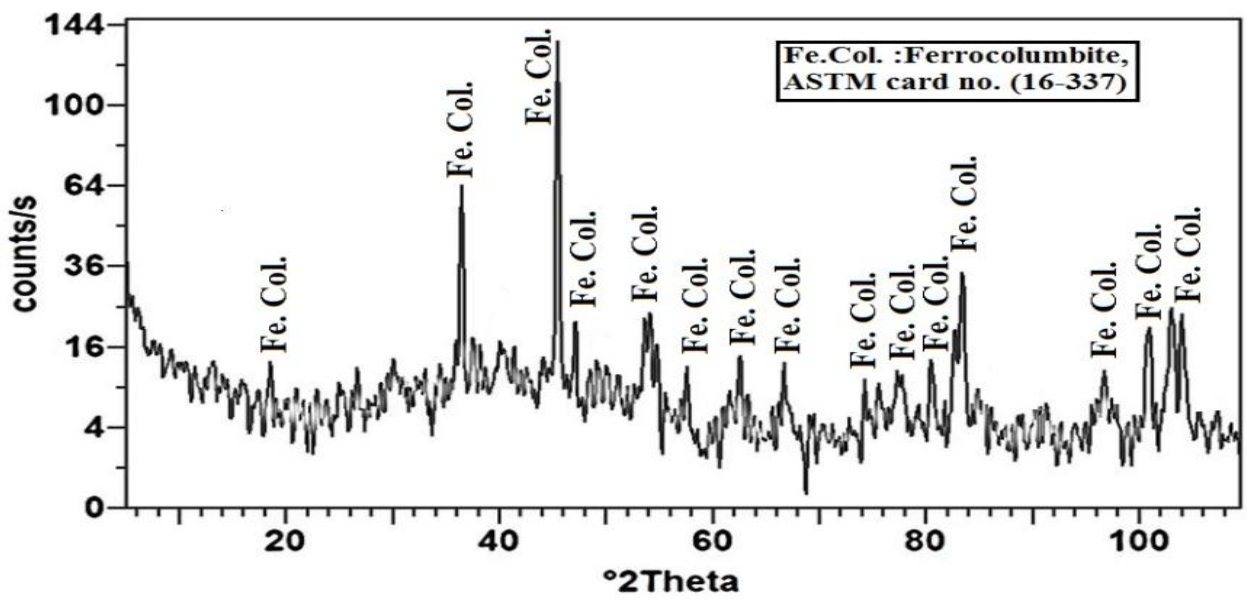

Fig 3:-X-Ray of $\mathrm{Nb}$ ore sample 


\section{Environmental Scanning Electron Microscope (ESEM)}

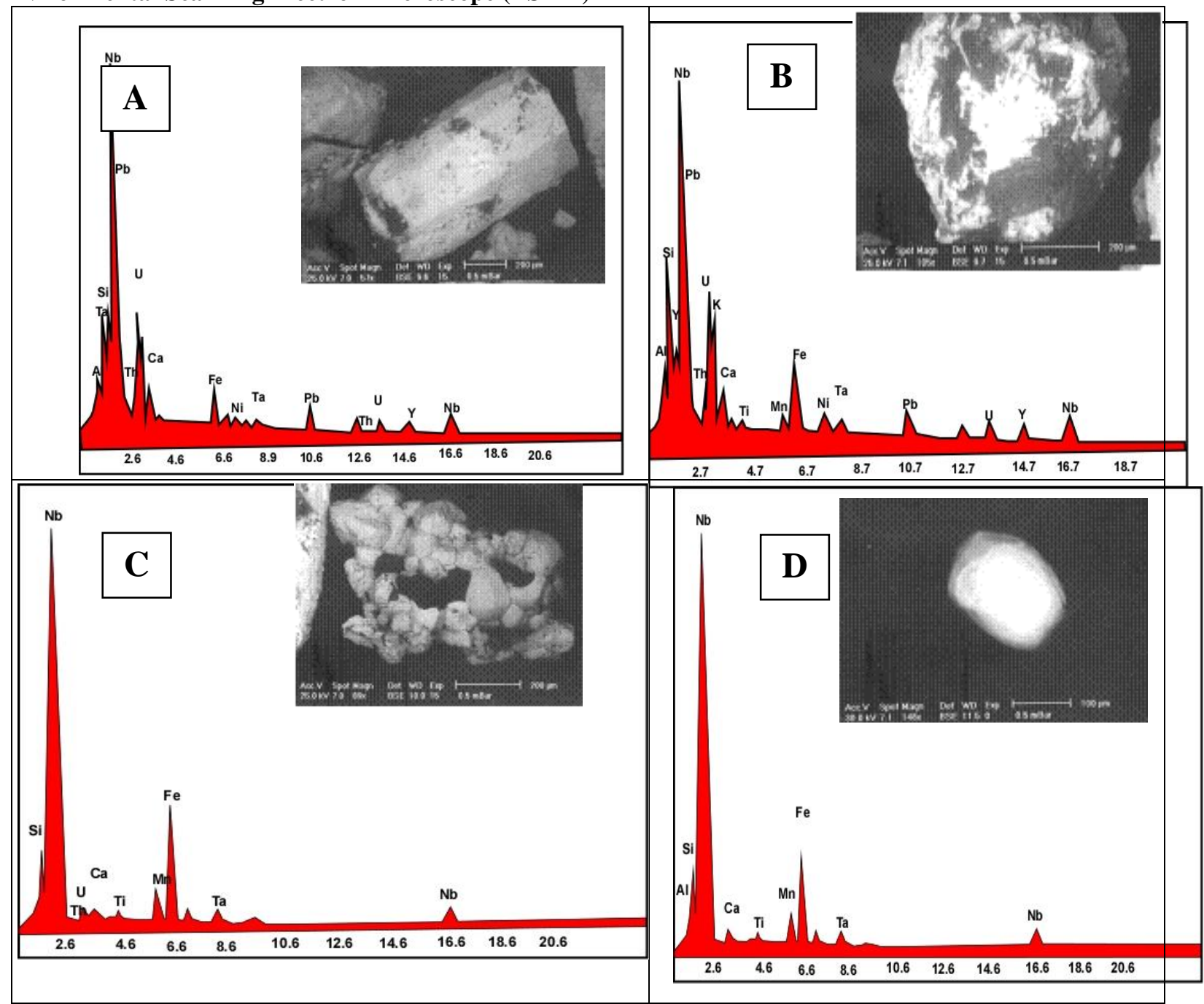

Figure 4:-EDX showing different varieties of columbite from Abu Rusheid mylonite.

\section{Recovery of Niobium and Tantalum}

Actually, the factors affecting solvent extraction process included solvent concentration, contact time, $\mathrm{pH}$ of the leach liquor and aqueous/ organic ratio (A/O). These factors were studied for both interesting metal values; $\mathrm{Ta}$ and $\mathrm{Nb}$.

\section{Effect of lauryl alcohol concentration}

This effect was studied upon the $\mathrm{Nb}$ and $\mathrm{Ta}$ extraction efficiency where in the case of $\mathrm{Nb}$ extraction by conducting equal volumes of the feeds solution (free from $\mathrm{Ta}$ ) with different solvent concentration ranging from $0.1 \mathrm{M}$ to $3 \mathrm{M}$ at a fixed contact time 15 mines at $\mathrm{pH} 0.25$ and $\mathrm{A} / \mathrm{O}$ phase ratio of $1: 3$. The result is plotted in fig. (5).From the results, it is clear that the extraction of niobium decrease gradually with increasing of alcohol concentration from $0.1 \mathrm{M}$ to $3 \mathrm{M}$, so, the best concentration of lauryl alcohol for $\mathrm{Nb}$ extraction is $0.1 \mathrm{M}$ in kerosene. But in the case of the feeds solution (free from $\mathrm{Nb}$ ) with different solvent concentration ranging from $0.1 \mathrm{M}$ to $3 \mathrm{M}$ at a fixed contact time 10 mines at $\mathrm{pH} 2$ and $\mathrm{A} / \mathrm{O}$ phase ratio of 1:3. The result is plotted in Fig. (5).From the results it is clear that the extraction of Ta decrease gradually with increasing of alcohol concentration from $0.1 \mathrm{M}$ to $3 \mathrm{M}$, so, the best concentration of lauryl alcohol for Ta extraction is $0.1 \mathrm{M}$ in kerosene. 


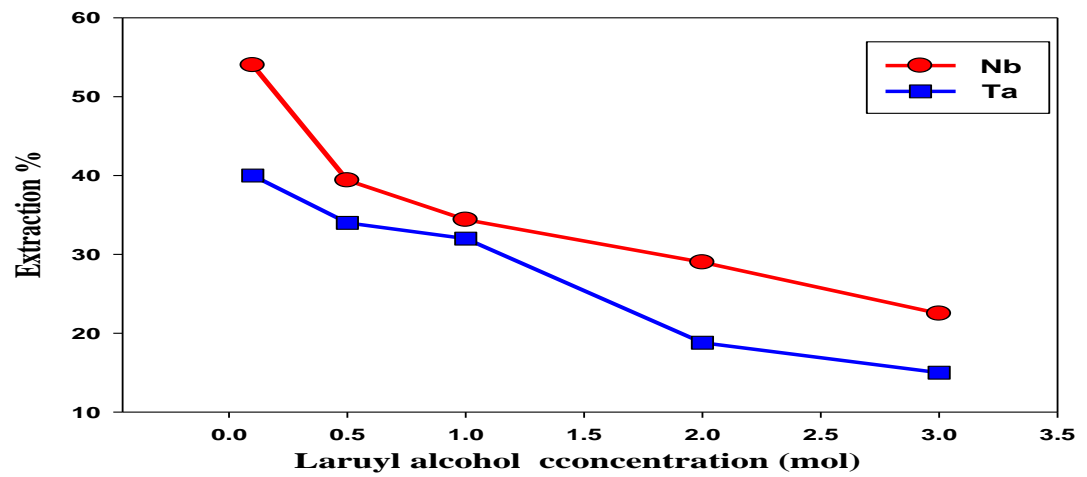

Figure 5:-Effect of Lauryl alcohol concentration up on extraction efficiency of $\mathrm{Nb}(\mathrm{V})$ and $\mathrm{Ta}(\mathrm{V})$

Effect of different diluents on the extraction process

Table (4) reveals that kerosene is the best diluent for both $\mathrm{Nb}(\mathrm{V})$ and $\mathrm{Ta}(\mathrm{V})$ extraction.

Table 4:-Effect of diluents on the extraction of $\mathrm{Nb}(\mathrm{V})$ and $\mathrm{Ta}(\mathrm{V})$ by $0.1 \mathrm{M}$ lauryl alcohol in kerosene

\begin{tabular}{|l|l|l|}
\hline Diluent & Extraction \%of Nb & Extraction \% of Ta \\
\hline Kerosene & 60 & 54.3 \\
\hline CCl4 & 49.1 & 51.8 \\
\hline Xylene & 49.1 & 46 \\
\hline Benzene & 45.2 & 38.8 \\
\hline Chloroform & 42.8 & 32 \\
\hline Toluene & 40.4 & 28.9 \\
\hline
\end{tabular}

\section{Effect of $\mathrm{pH}$ of feed solution}

To study the effect of $\mathrm{pH}$ of the feed solution upon $\mathrm{Nb}$ extraction efficiency, different $\mathrm{pH}$ values ranging from 0.1 to 2 of the feed solution were conducted while fixing the other extraction conditions $0.1 \mathrm{M}$ lauryl alcohol and $\mathrm{A} / \mathrm{O}$ ratio 1:3, the corresponding $\mathrm{Nb}$ extraction efficiencies are show in Fig. (6), from the results obtained it is obvious that increasing the $\mathrm{pH}$ from 0.1 to 2.0 , decreases the extraction of $\mathrm{Nb}$ from $54 \%$ to $39.6 \%$. So it can be concluded that the best $\mathrm{pH}$ for $\mathrm{Nb}$ extraction at 0.25 and for $\mathrm{Ta}$ at 2.0.

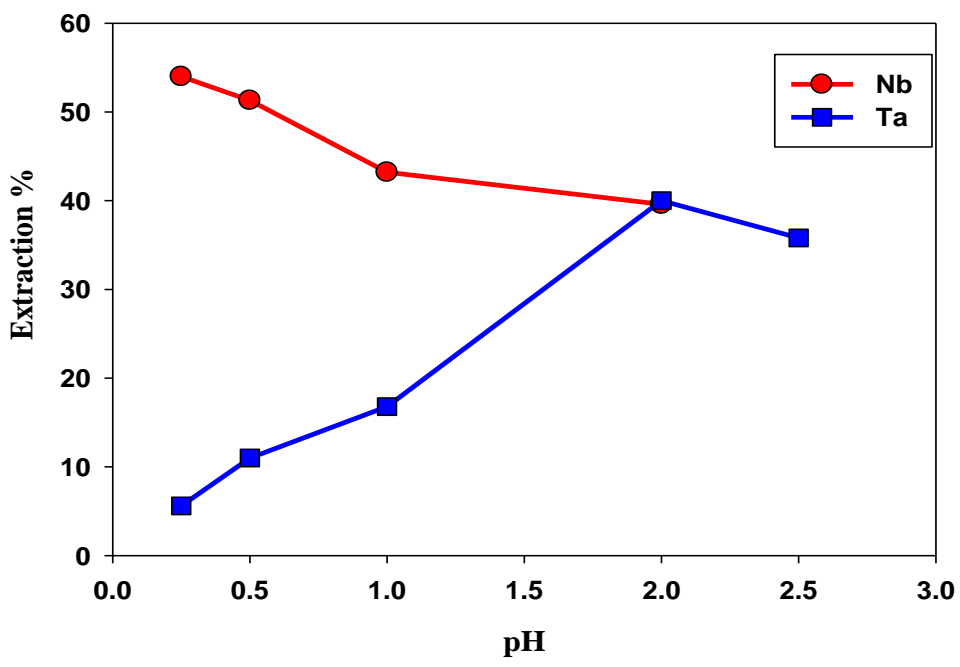

Fig 6:-Effect of $\mathrm{pH}$ upon the extraction of $\mathrm{Nb}(\mathrm{V})$ and $\mathrm{Ta}(\mathrm{V})$ 


\section{d. Effect of contact time on the extraction process}

To study the effect of contact time upon the extraction of $\mathrm{Ta}$ and $\mathrm{Nb}$ be $0.1 \mathrm{M}$ lauryl alcohol in kerosene, set-of excrement was performed at different contact time while fixing the other extraction factors at $\mathrm{A} / \mathrm{O}$ phase ratio of 1:3, 0.1 M lauryl alcohol in kerosene and $\mathrm{pH} 0.25$ for $\mathrm{Nb}$ and $\mathrm{pH} 2.0$ for Ta. The data are plotted in Fig. (7). From the results obtained, it is clear that increasing the time from 5 to $15 \mathrm{~min}$. increase Ta extraction efficiency to $54 \%$ and $60 \%$ for $\mathrm{Nb}$. So it is conducted that the contact time for maximum extraction of $\mathrm{Ta}$ and $\mathrm{Nb}$ was 15 minutes.

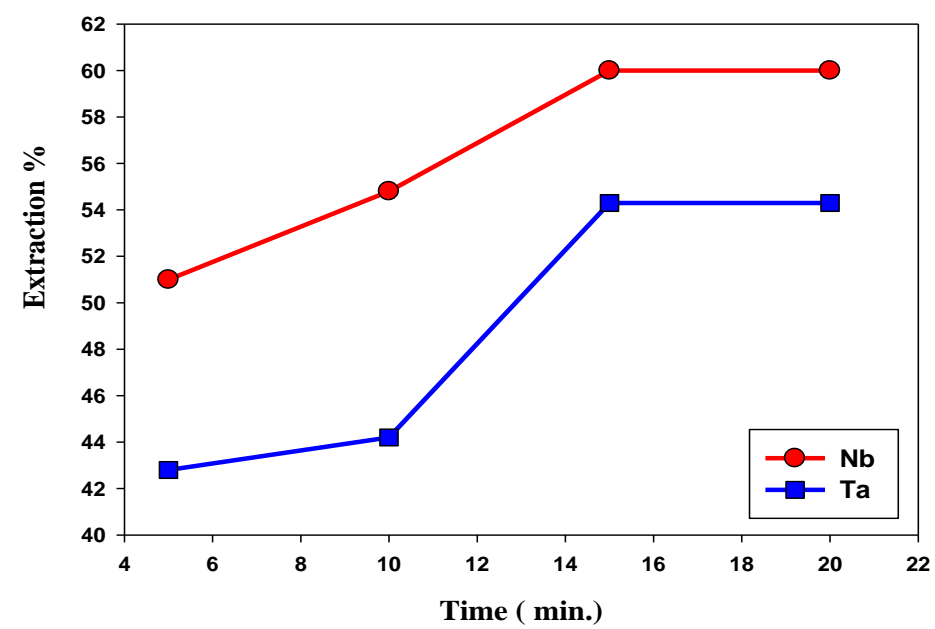

Figure 7:-Effect of contact time on the extraction of $\mathrm{Nb}(\mathrm{V})$ and $\mathrm{Ta}(\mathrm{V})$

Effect of $\mathrm{A} / \mathrm{O}$ phase ratio on the extraction of $\mathrm{Nb}$ and $\mathrm{Ta}$

As it is clear from Figure (8) the best $\mathrm{A} / \mathrm{O}$ phase ratio is $1: 3$ in both $\mathrm{Ta}$ and $\mathrm{Nb}$ prevent extraction.

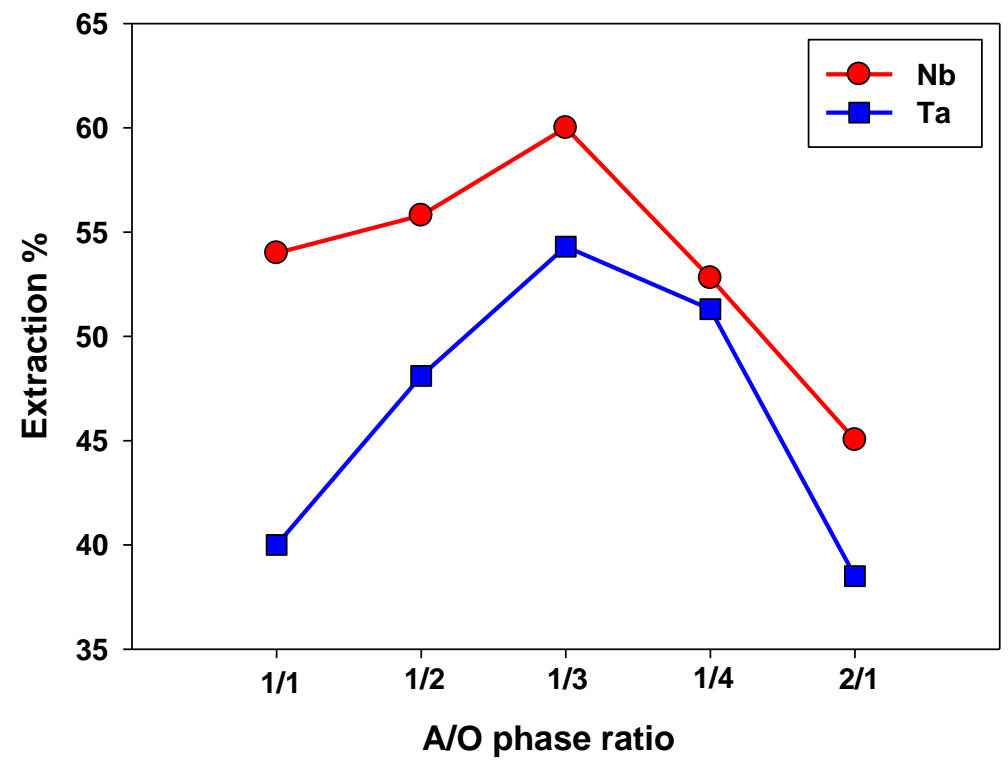

Figure 8:-Effect of A /O phase ratio on the extraction of $\mathrm{Ta}(\mathrm{V})$ and $\mathrm{Nb}(\mathrm{V})$

Effect of temperature upon the extraction of $\mathrm{Nb}(\mathrm{V})$ and $\mathrm{Ta}(\mathrm{V})$

The present factor is studied between $10^{\circ} \mathrm{C}$ and $60^{\circ} \mathrm{C}$. It is obvious that room temperature give the best extraction for $\mathrm{Ta}$ and $\mathrm{Nb}$. This shows that reaction is exothermic. 


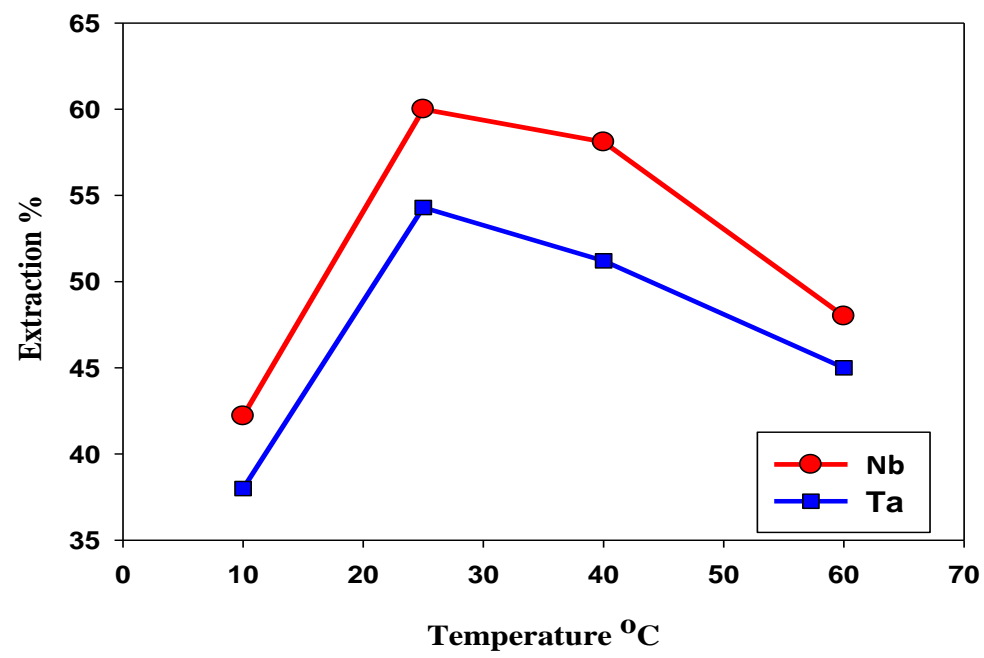

Figure 9:-Effect of temperature upon the extraction of $\mathrm{Nb}(\mathrm{V})$ and $\mathrm{Ta}(\mathrm{V})$.

It is clear from fig. (9) that room temperature is the best temperature for the two metallic elements.

\section{Stripping}

Effect of different stripping reagent on the stripping process

Table 5:-Effect of different stripping reagent on the stripping of $\mathrm{Nb}(\mathrm{V})$ :

\begin{tabular}{|l|l|}
\hline Stripping reagent & \% Stripping Nb \\
\hline $0.5 \mathrm{M} \mathrm{H}_{2} \mathrm{SO}_{4}$ & 24.8 \\
\hline $5 \mathrm{M} \mathrm{H}_{2} \mathrm{SO}_{4}$ & 68.1 \\
\hline $7 \mathrm{M} \mathrm{HF}+6 \mathrm{M} \mathrm{H}_{2} \mathrm{SO}_{4}$ & 57.4 \\
\hline $10 \mathrm{M} \mathrm{HF}$ & 35.8 \\
\hline $10 \mathrm{M} \mathrm{H}_{2} \mathrm{SO}_{4}$ & 41.3 \\
\hline
\end{tabular}

It is clear from Table (5) that $5 \mathrm{M} \mathrm{H}_{2} \mathrm{SO}_{4}$ give is the highest stripping value for $\mathrm{Nb}$.

Table 6:-Effect of different stripping reagent on the stripping of Ta (V)

\begin{tabular}{|l|l|}
\hline Stripping reagent & \% Stripping Ta \\
\hline Distilled water & 75 \\
\hline $0.5 \mathrm{M} \mathrm{HF}$ & 20.8 \\
\hline $0.5 \mathrm{M} \mathrm{H}_{2} \mathrm{SO}_{4}$ & 25.3 \\
\hline $0.7 \mathrm{M} \mathrm{H}_{2} \mathrm{SO}_{4}+0.5 \mathrm{M} \mathrm{HF}$ & 38.3 \\
\hline
\end{tabular}

The best stripping reagent for stripping $\mathrm{Ta}$ is distilled water where $75 \mathrm{Ta}$ stripping \% is obtained (Table $6)$.

Effect of contact time on the stripping process of $\mathrm{Nb}(\mathrm{V})$ and $\mathrm{Ta}(\mathrm{V})$ :

It is clear from Fig. (11) that at contact time of 10 mines, gives the highest stripping value for $\mathrm{Ta}$ $(98.6 \%)$ and $\mathrm{Nb}(94.5 \%)$. 


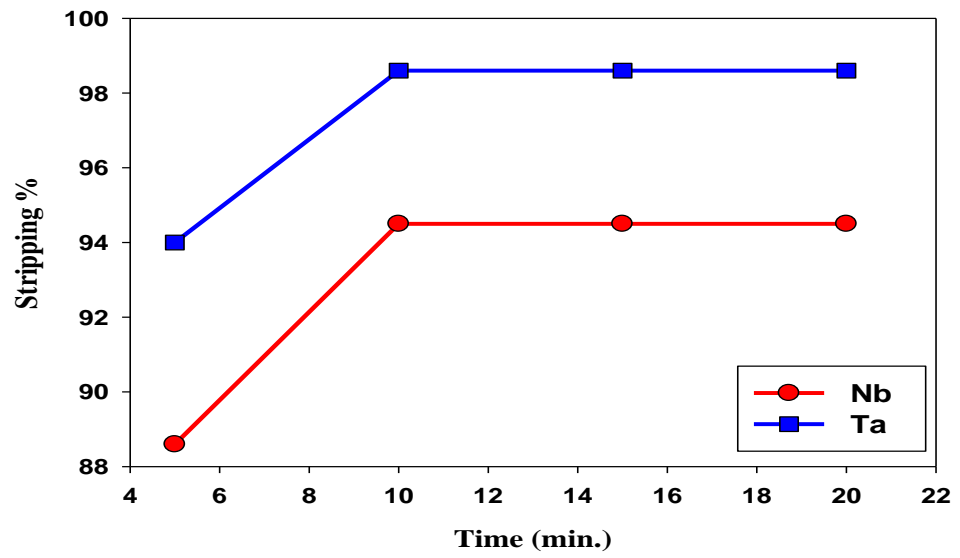

Fig 10:-Effect of contact time on the stripping of $\mathrm{Nb}(\mathrm{V})$ and $\mathrm{Ta}(\mathrm{V})$

Effect of aqueous / organic phase ratio on the stripping process of $\mathrm{Nb}$ (two stages) and Ta

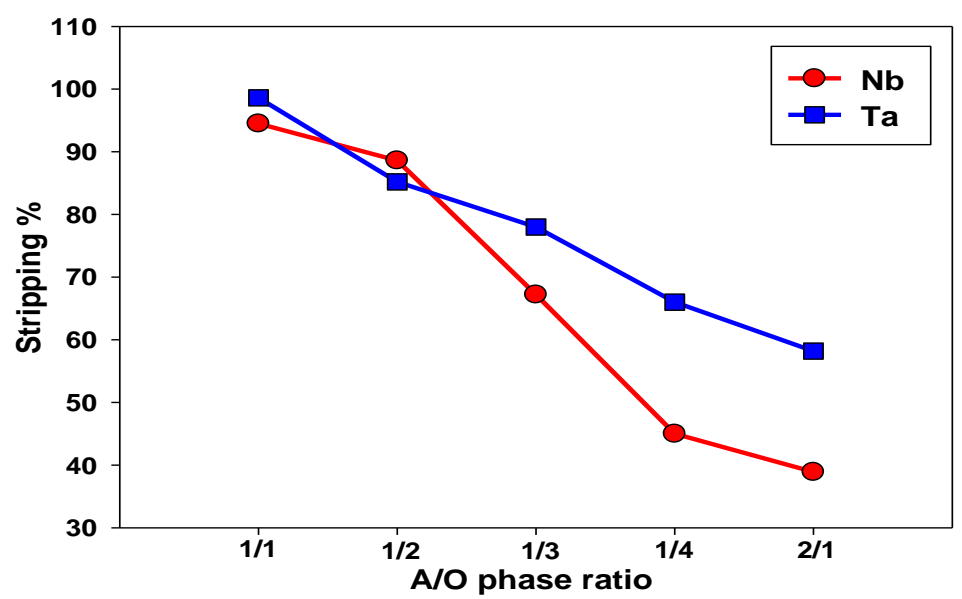

Fig 11:-Effect of A / O phase ratio on the stripping of $\mathrm{Nb}(\mathrm{V})$ (Two Stages) and $\mathrm{Ta}(\mathrm{V})$ (Two Stages).

It is clear from Fig. (11) that $1: 1$ is the best stripping $\mathrm{A} / \mathrm{O}$ phase ratio for both $\mathrm{Nb}$ and $\mathrm{Ta}$.

Effect of temperature on the stripping process

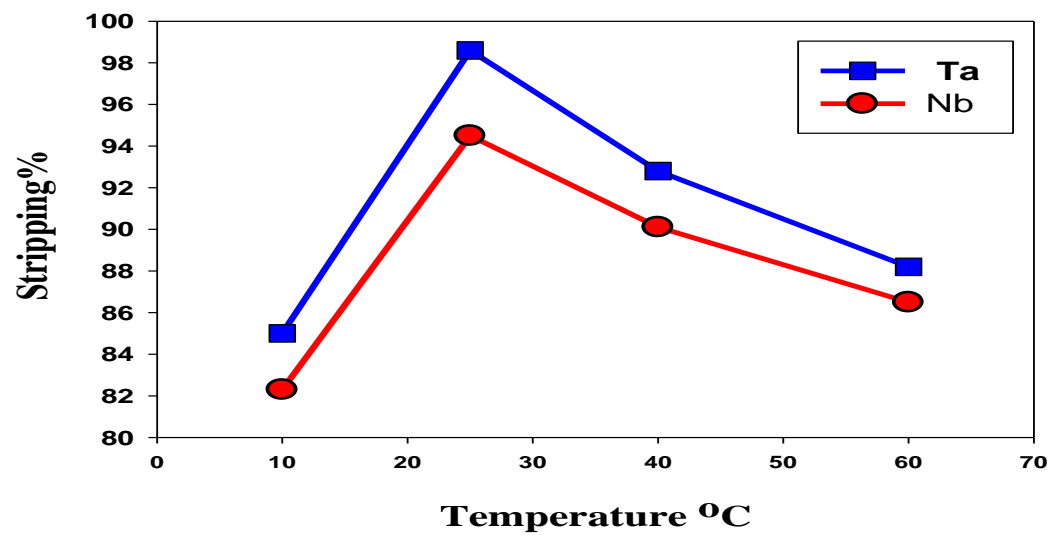

Fig 12:-Effect of Temperature on the stripping of $\mathrm{Nb}(\mathrm{V})$ and $\mathrm{Ta}(\mathrm{V})$. 
From Fig. (12) it is clear that room temperature give the highest stripping \% for Ta 98.6 and $\mathrm{Nb} 94.5 \%$ Activation energy.

\section{Construction of McCabe - Thiele diagram for Nb Extraction}

McCabe - Thiele diagram is a compos diagram composed of two lines an equilibrium line and an operating line. It is shown from the diagram that two stage stripping is adequate for both $\mathrm{Nb}$ and $\mathrm{Ta}$ extraction and stripping.

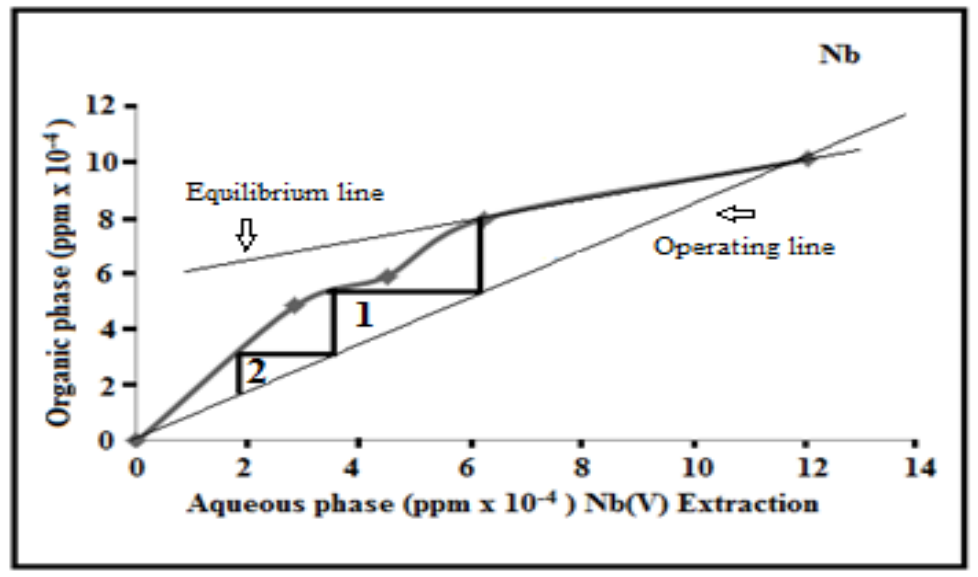

Fig 13:-McCabe - Thiele diagram for Nb extraction

It is clear from the obtained McCabe - Thiele diagram for $\mathrm{Nb}$ stripping the two stages. Stripping gives the highest $\mathrm{Nb}$ value at a phase ratio of 1:1 (Figs.13 \&14).

\section{Construction of McCabe - Thiele diagram for Nb Stripping}

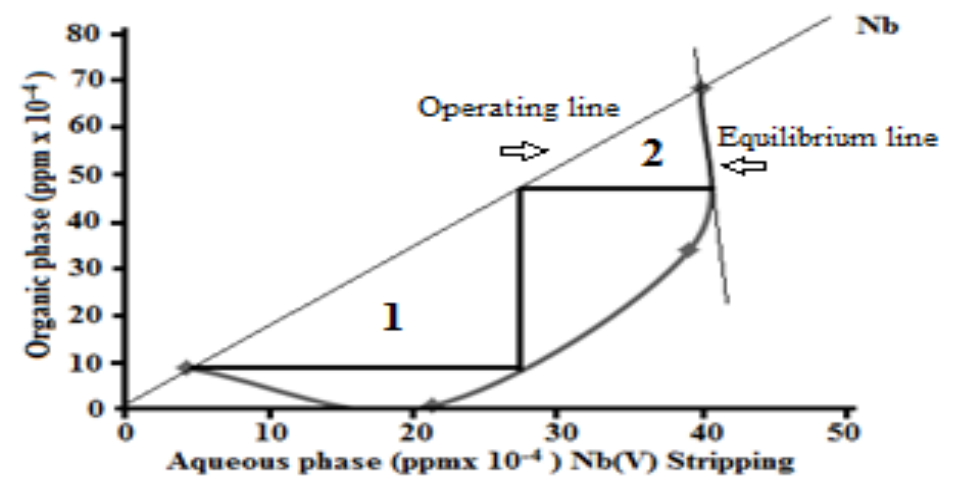

Figure 14:-McCabe - Thiele diagram for Nb stripping

Construction of McCabe - Thiele diagram for Ta Stripping: aqueous

$\mathrm{McCab}$ - Thiele diagram is composed of two lines a) Equilibrium line and b) Operating line (Figs.15\&16). 


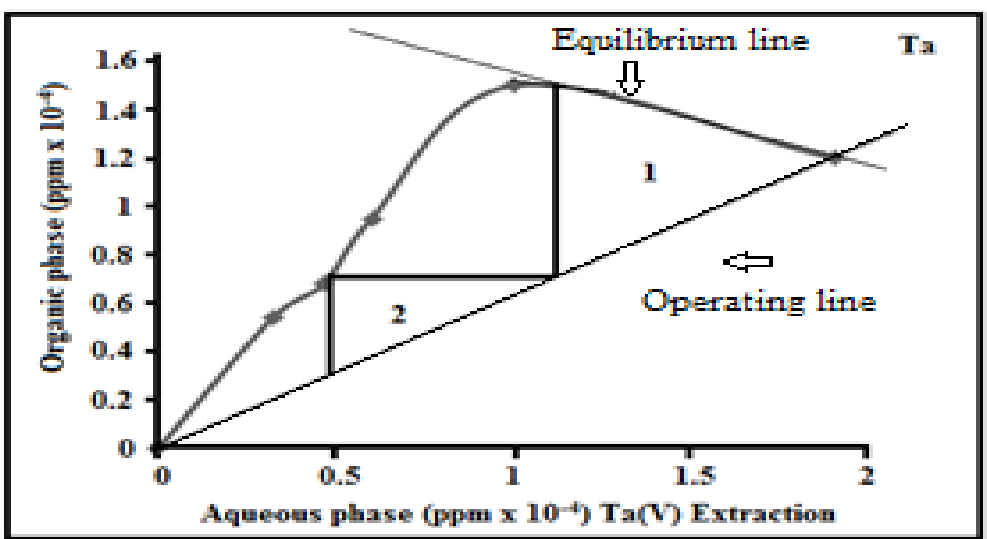

Fig 15:-McCabe- Thiele diagram for Ta extraction

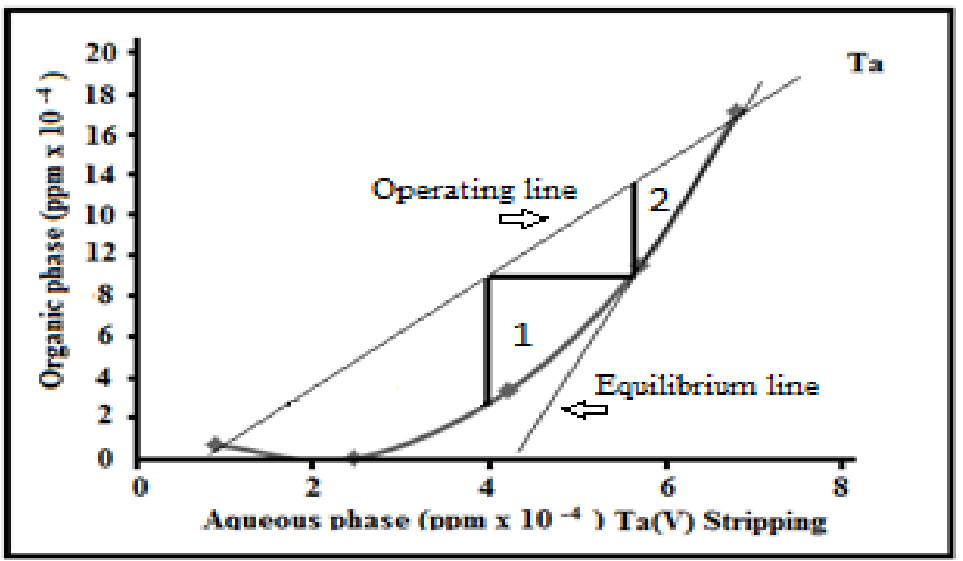

Fig 16:-McCabe- Thiele diagram for Ta stripping

\section{Precipitation of both $\mathrm{Ta}$ and $\mathrm{Nb}$}

Precipitation of $\mathrm{Ta}$ is achieved by ammonia at $\mathrm{pH}$ 4.5-5.5 while that of $\mathrm{Nb}$ by ammonia at $\mathrm{pH}$ 67.5.Calculation of these precipitate at $650{ }^{\circ} \mathrm{C}$ for $3 \mathrm{hr}$ give $\mathrm{Ta}_{2} \mathrm{O}_{5}$ and $\mathrm{Nb}_{2} \mathrm{O}_{5}$ in a pure forms. Final product as shown in EDX for $\mathrm{Nb}(\mathrm{V})$ and $\mathrm{Ta}(\mathrm{V})$ (Figs. $17 \& 18$ ). Finally a technological flow sheet is proposed for each $\mathrm{Nb}$ and $\mathrm{Ta}$ (Fig.19).

\section{Characterization of product:}

Environmental Scanning Electron Microscope (ESEM):

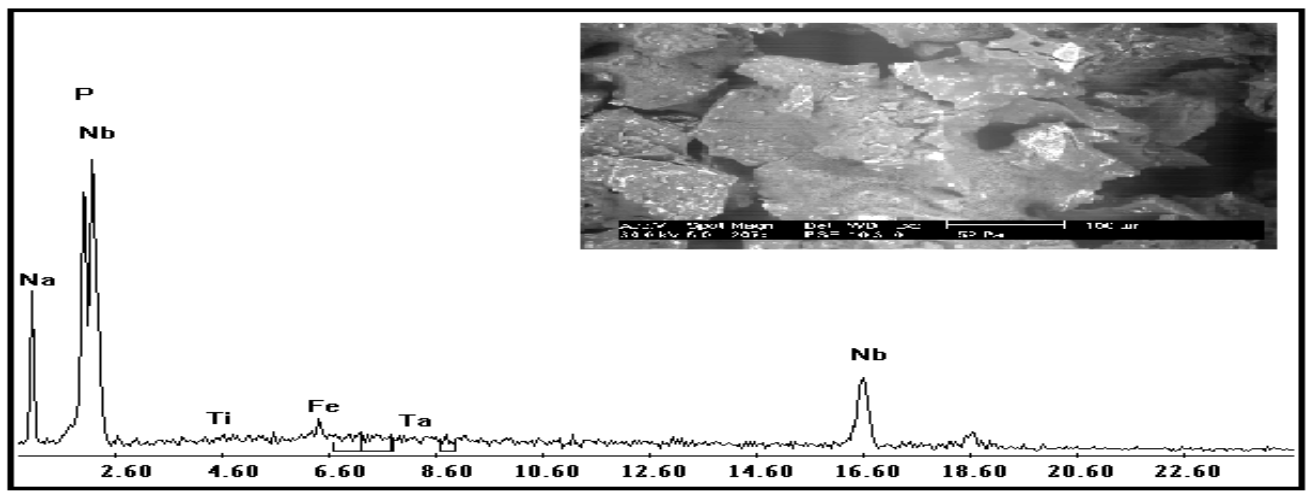

Figure 17:-EDX and backscattered images of $\mathrm{Nb}$ product 


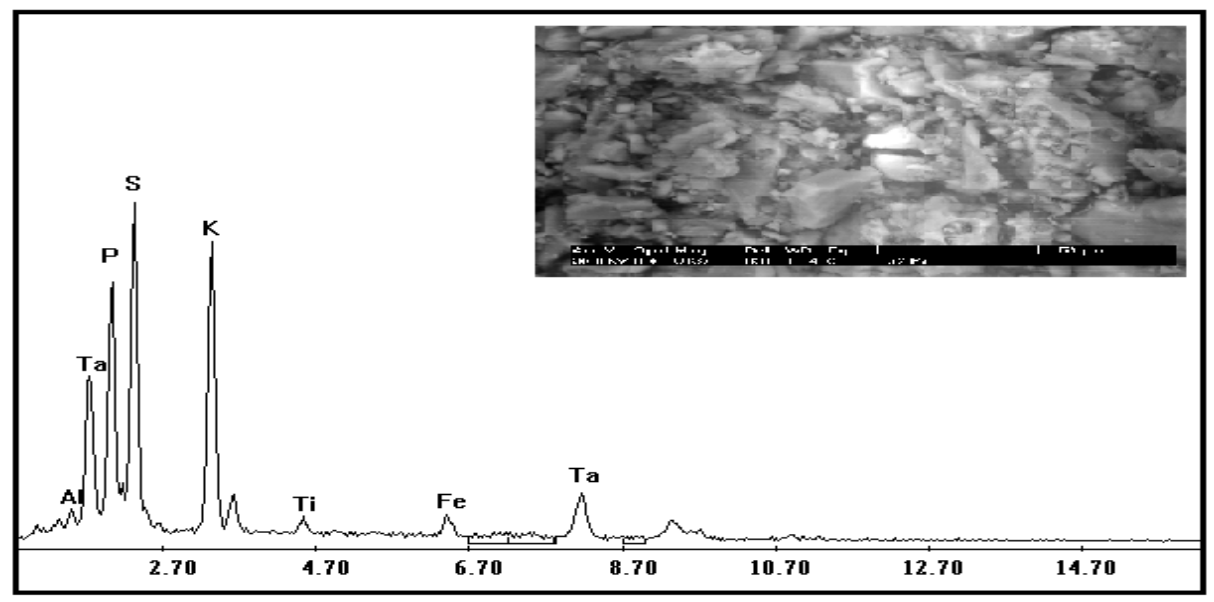

Figure 18:-EDX and backscattered images of Ta product

\section{Infrared spectroscopy (FTIR)}

Figures $(3,4 \& 5)$ show infrared transmission spectra of Tantalum, Niobium and a mixture of $\mathrm{Nb}$ and $\mathrm{Ta}$ (study sample) in the range $4000-400 \mathrm{~cm}^{-1}$.

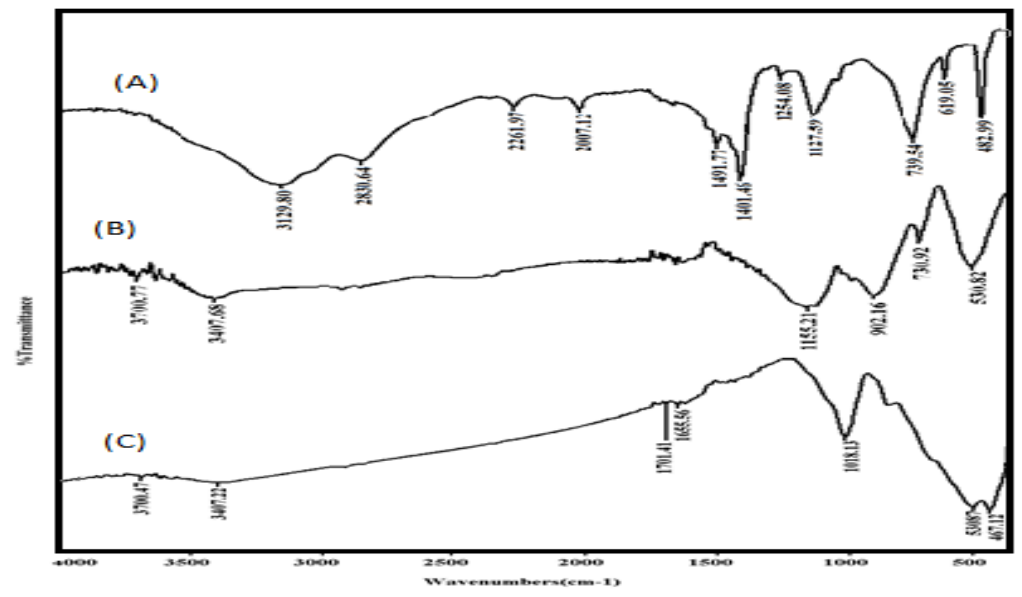

Fig 19:-FTIE of $\mathrm{Nb}$ and $\mathrm{Ta}$ ore and product

Where $(\mathrm{A})=$ FTIE of Ta $(\mathrm{V})$ precipitate.

\section{(B) = FTIE of $\mathrm{Nb}(\mathrm{V})$ precipitate. \\ (C) = FTIE of Nb and Ta Ore}

In Fig. (19) (C) The splitting of Nb-O stretching vibration peaks at $590.52 \mathrm{~cm}^{-1}$ and the Ta $-\mathrm{O}$ stretching vibration peaks at $467.12 \mathrm{~cm}^{-1}$ is an indication of $\mathrm{Nb}$ and Ta ore. This bands is shown only as one peak at $428.99 \mathrm{~cm}-1$ for Ta Fig. (19 A) and 530.18 as Nb Fig. (19 B).The bending mode of Nb-O and Ta-O stretching vibration bay outside the range of the infrared instrument. 


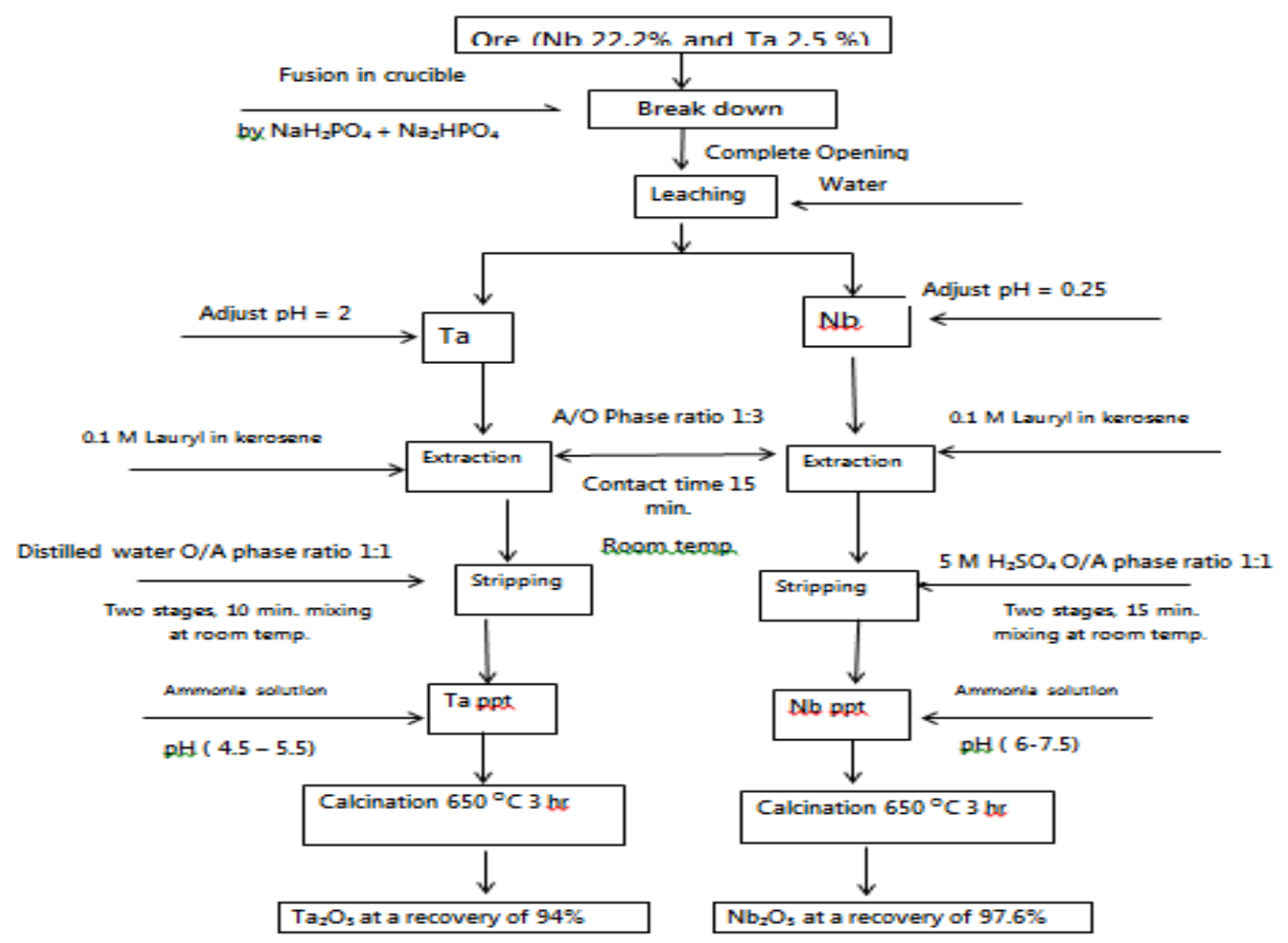

Fig 20:-Proposed technical flow sheet for extraction of $\mathrm{Ta}(\mathrm{V})$ and $\mathrm{Nb}(\mathrm{V})$ from ore material

\section{Conclusion:-}

The $\mathrm{Nb}$ - Ta mineralization (columbite) at Abu Rusheid area has been estimated as a big deposit accounting for ore reserves of 13, 000 tons of $\mathrm{Ta}_{2} \mathrm{O}_{5}$ and 90,000 tons of $\mathrm{Nb}_{2} \mathrm{O}_{5}$ in contents amounting to 0.02 and of $0.14 \%$ respectively (Sabet et, al; 1976). Abu Rusheid inferred resources above Wadi Abu Rusheid level are calculated on the basis of ore grade $0.01 \% \mathrm{Ta}$ and $0.05 \% \mathrm{Nb}$ as follows: 86.170 tons $\mathrm{Nb}$ and 8.6 tons Ta (Ibrahim et al., 2008 \& 2018).

Ore characterization has first been prepared chemical analysis revealed the presence of valuable metal oxide involve 22.4 in wt. $\% \mathrm{Nb}_{2} \mathrm{O}_{5}$ as well as 2.4 in wt.\% $\mathrm{Ta}_{2} \mathrm{O}_{5}$ due to the refractory mature of the studied ore material, a breakdown by equal mixture of dihydrogene phosphate monohydrate and disodium hydrogen phosphor for complete decomposition filtered by water leaching.

Recovery of interesting metals $(\mathrm{Nb}$ and $\mathrm{Ta}$ ) from bisulphate leach liquor involved several steps first extraction with $0.1 \mathrm{M}$ lauryl alcohol in kerosene as a new solvent at $\mathrm{pH} 0.25$ for $\mathrm{Nb}$ and contact time 15 $\mathrm{ml} / \mathrm{min}$. in a one stage followed by stripping in two stages with $5 \mathrm{M} \mathrm{H}_{2} \mathrm{SO}_{4}$ and $\mathrm{Nb}$ precipitation with ammonia at $\mathrm{pH}$ 6-7.5 followed by calcinations at $650{ }^{\circ} \mathrm{C}$ for $3 \mathrm{hr}$. A pure $\mathrm{Nb}_{2} \mathrm{O}_{5}$ is obtained at a recover of $94.5 \%$, whereas $\mathrm{Ta}$ is extracted at $\mathrm{pH} 2.0$ with $0.1 \mathrm{M}$ lauryl alcohol in kerosene at a contact time of 15 $\mathrm{ml} / \mathrm{min}$. Stripping with water in two stages and precipitation with ammonia at $\mathrm{pH}$ 4.5-5.5, followed by calcinations at $650^{\circ} \mathrm{C}$ for 3 hrs. A pure $\mathrm{Ta}_{2} \mathrm{O}_{5}$ is obtained at a recovery of $98.6 \%$ (Fig.18). Finally a technical flow sheet is given for processing of studied ore as show in Figure (20).

\section{Acknowledgement:-}

The authors thank Prof. / Dr. Mohamed M. Ismail Nuclear Materials Authority, Cairo, Egypt, previous head of the Ore Dressing Dept., for improving the grade of the ore to 22.5\% Niobium and 2.5\% Tantalum by physical upgrading methods. 


\section{References:-}

1. Amer, T.E., (2007): Recovery of Niobium and Tantalum from the preprocessed multiple-oxide ore material of Gabal Abu Dob, Eastern Desert, Egypt. Ain Shams Education Bulletin of Science

2. Anatoly, A., Ludmily, A., Viktor, F.T., (2004): Liquid-liquid extraction of tantalum with 2 octanol. Chemical Engineering and Processing43, 1231-1237p.

3. El Hazek, M.N., (2001): Recovery of Uranium, Niobium and Tantalum from Kadabora Uraniferous Pegmatite. Eastern Desert, Egypt, PhD. Thesis, Faculty of Science, Ain Shams University.

4. El Hussaini, O.M., (1996): Extraction of Niobium and Tantalum Elements from Some Egyptian Ore Materials. Ph.D. Thesis, Faculty of Science, Cairo University

5. El-Hazek M.N., Amer, T.E., Abu El Azim, M.G., Issa, R.M.and Hady, S.M. (2009): breakdown of polymerized soul Gabal El Aurf of ore material under publication Arab journal of chemistry king Saudi Arabia.

6. El-Hazek, M.N., Amer, T.E., Abu El-Azm, M.G., Issa, R.M., Omar, S.A., El-Hady, S.M., (2010): liquid liquid extraction of Tantalum and Niobium by octanol from sulphate leach liquor, Submitted for publication. Journal of Faculty of Education, Ain Shams University, Cairo, Egypt.

7. Hintemann R., Trotz verbesserter, Energieeffizienz steigt der Energiebedarf der deutschen, Rechenzentren, (2018): Berlin, Germany; [Accessed: 13/06/2018].

8. Ibrahim, M. E, G.M. Saleh, M. S. Kamar, S.M. Saleh, A.M. El- Tohamy and E.A. Quraney (2018): Uranium and Gold mineralization in Mylonite and Mica Schist, at Wadi Abu Rusheid, South Eastern Desert, Egypt (Internal report, at NMA, Egypt)

9. Ibrahim, M. E., Saleh, G. M., Amer, T., Mahmoud, F.O., Abu El Hassan, A. A., Ibrahim, I. H., Aly, M. A., Azab, M. S., Rashed, M. A., Khaleal, F, M. and Mahmoud, M. A., (2002): Uranium and associated rare metals potentialities of Abu Rusheid brecciated shear zone II, Southeastern Desert, Egypt. (Internal report, at NMA, Egypt).

10. Ibrahim, M. E., Saleh, G. M., Ibrahim, I. H., Amer, T, Mahmoud, F. O., Abu El Hassan, A. A., Aly, M. A., Azab, M. S., Rashed, M. A., Khaleal, F. M. and Mahmoud, M. A.,(2004): Uranium and associated rare metals potentialities of Abu Rusheid brecciated shear zone II, south Eastern Desert, Egypt. (Internal report, at NMA, Egypt).

11. Ibrahim, M. E., Saleh, G. M., Mahmoud, F. O., Abu El Hassan, A. A., Ibrahim, I. H., Rashed, M. A., Khalel, F. M. and Mahmoud, M. A., (2008): Geochemical Evaluation for Trace Elements Associated with Cataclastic rocks, Abu Rusheid area, South Eastern Desert, Egypt, (Internal report, at NMA, Egypt).

12. Kasikava, N.I., Kasikov, A.G.,and Korotkora, G.V.,(2009): Extraction of Niobium from hydrochloric solutions with Tertiary amines was Aprotic Diluents, Russam Journal of applied chemistry Vol. 16, No. 1 of 424-429p.

13. Kasockava, N.J, Kosikov, A.G.and Kouthova G.V., (2010): Russan Journal of applied chemistry vol 83No. 3, 424-429p.

14. Kumar, N., Sundaresan, A., Rao, C.N.R.., (2011): Rare earth niobium oxynitrides, Ln $\mathrm{NbON}_{2}$-d (Ln $=\mathrm{Y}, \mathrm{La}, \mathrm{Pr}, \mathrm{Nd}, \mathrm{Gd}, \mathrm{Dy})$ : synthesis, structure and properties. Mater Res Bull. 46(11)

15. Maiorov, V.G. et al., (2010): Extractive recovery of $\mathrm{Ta}(\mathrm{V})$ and $\mathrm{Nb}(\mathrm{V})$ with octanol from HF acid solutions containing large amounts ofTi (IV). Russian Journal of Applied Chemistry 74 (6)

16. Maiorov, V.G., Kirickenko, N. V., Elkaravo, I.P and A. Safanova, L.A., (2015): Theoretical foundation of chemical Engineering vol 48 No. 4 pp530-539p.

17. Maiorov, V.G., Muclark, N.V, Nickolacy, H. F., Elizarova, I.R.,and Safonova,L.A., (2016): Theoretical Foundation of chemical Engineering Vol .50 No. 5, 781-784p.

18. Mariorov, V.G., Kirichenk, I. A., Elizoral, IRSafonover L.A., and Nckolove , A. I., (2013):The theoretical Foundation of chemical Enginerringvol 47 No. 94 pp 980-483 p.

19. Mehmet, Ali, Kucuker1, Xiaochen, Xu1 and Kerstin, Kuchta1, (2018): Extraction Potential of Tantalum from Spent Capacitors through Bioleaching. Springer-Verlag GmbH Deutschland, ein Teil von Springer Nature 2019 A. Pehlken et al. (Eds.), Cascade Use in Technologies .

20. Nikolaev, A.I., criehenko, N. V., and Maiorov, V.G., (2009): ISSNOO36-0236RussanJournal of Inorganic chemistry vol 24 p.505-54p.

21. Nikolaev, A.I., Mayorov, V.G., (2002): Tantalum (V) and niobium (V) extraction by octanol. Hydrometallurgy 66, 77-83p. 
22. Sabet, A. H., Tsogoev, V. B., Bordonosov, V. P., Shablovsky, R. G., and Kosa, M., (1976): On the geologic structure, laws of localization and prospects of Abu Rusheid rare metals deposit. Annals of the Geological Survey of Egypt.Vol, VI.

23. Sosa, G. M., Augsburger, M. S., and Pedregosa, J. C., (2002): Columbite-group minerals from raremetal granitic pegmatites of the Sierra de San Luis, Argentina, 181- 190p.

24. Wang, F., Zhao, T.P., Chen, W., (2012): Advances in study of Nb-Ta ore deposits in Panxi area and tentative discussion on genesis of these ore deposits. Miner Depos. 2012; 31(2):293p.

25. Zhang, P.S, Tao., K.J., Yang ZM, Yang, XM, Song, R.K.,(2011): Genesis of rare earth, niobium and tantalum minerals in Bayan Obo ore deposits of China. J Chin Soc Rare Earths. 19(2):97p.

26. Zhou M, Rivarola J, Ruiz MD.(2004): The effects of carboxylic acid addition on hydrofluoric acid autoclave leaching of a ferrcolumbite. Hydrometallurgy. , 74(1-2):39p.

27. Zhou XH, Zheng SL, Xu HB, Zhang Y.(2011): Leaching of niobium and tantalum from a low-grade ore using a $\mathrm{KOH}$ roast-water leach system. Hydrometallurgy. 98(3-4):219p.

28. Zhou, HM, Zheng SL, Zhang Y, Yi DQ. (2005): A kinetic study of the leaching of a low-grade niobium-tantalum ore by concentrated $\mathrm{KOH}$ solution. Hydrometallurgy. 80:170p. 